\title{
The Use of Fragment-identification to Demonstrate Short-term Changes in the Diet of Rabbits
}

\author{
J. Marijke WALLAGE-DREES ${ }^{1}$, Herman J. IMMINK ${ }^{2}$, \\ Gerrit-Jan DE BRUYN ${ }^{1}$, \& Pieter A. SLIM ${ }^{*}$
}

\begin{abstract}
Wallage-Drees J. M., Immink H. J., De Bruy'n G.-J. \& Slim P. A., 1986: The use of fragment-identification to demonstrate short-term changes in the diet of rabbits. Acta theriol., 31, 22: 293-301 [With 3 Tables \& 3 Figs.]

Microscopical analysis of epidermal fragments in stomach contents or faeces is a helpful tool in assessing the diet of herbivores. Two aspects can cause differences between stomach and faecal samples and should be taken into account establishing correction factors for diet composition: (1) differential digestion or retention of different plant species or plant parts; and (2) differences between meals (short-term changes in diet). In the present study faeces mean/stomach mean presence of a plant species is interpreted as a measure of digestibility and used as conversion factor for differential digestion of that species. By application of cluster analysis to the modified stomach and faecal contents it is revealed that some rabbits, Oryctolagus cuniculus (Linnaeus, 1758), have shifted their foraging areas during the night. Observations on short-term changes in the diet give information on foraging behaviour in a heterogeneous environment.

[1 Department of Population Biology, University of Leyden, P.O.Box 9516, 2300 RA Leiden, The Netherlands and 2 Department of Botany, Research Institute for Nature Management, P.O.Box 46, 3956 ZR Leersum, The Netherlands]
\end{abstract}

\section{INTRODUCTION}

Histological identification of plant fragments in stomach contents or faeces is commonly used for analysing the diet of wild herbivores (Bhadresa, 1982; Chapuis \& Lefeuvre, 1980). To recognize plant species the prints of the epidermal structure on the cuticula constitute a helpful tool.

Differences between stomach and faecal contents are usually ascribed to differential digestion or retention of foodplants (Batzli \& Pitelka, 1971; Neal et al., 1973; Owaga, 1977). Differential digestion means that some food particles are digested more fully on their way through the gastro-intestinal tract than others. Actually the waxen cuticula is never digested, but can become unidentifiable (Neal et al., 1973).

It has been realized that differential digestion or retention complicates the quantitative analysis of the diet from faeces composition. To calculate conversion factors for the main food-plants Bhadresa (1982) 
did experiments with captive rabbits, relating the proportions in the faeces to the proportions consumed.

Analyzing stomach and faeces contents of the same animals seems a time saving method to determine the degree of differential digestion for all foodplants. Wydeven \& Dahlgren (1982), however, mentioned short-term changes in the diet as the major cause of dissimilarities between stomach and faeces samples. In the present contribution we will explore the field of differences between stomach and faeces more systematically.

This study forms part of an extensive research program by the Research Institute for Nature Management on the influence of grazing by ponies and rabbits on the succession of the vegetation in the nature reserve Baronie Cranendonck in the Netherlands (Van de Laar \& Slim, 1979; Oosterveld, 1983). In this study it was necessary to know the habitat use of the rabbits. We studied to what extent one can get information on habitat use by the technique of fragment-identification.

\section{STUDY AREA}

The study area $\left(51^{\circ} 18^{\prime} \mathrm{N} ; 5^{\circ} 33^{\prime} \mathrm{E}\right)$. is situated south of Eindhoven, near the Belgian border. The site within the reserve where this study was conducted covers sea. 100 ha of woodland, heathland with drift sands, and abandoned arable fields (Fig. 1).

The woodlands consist of 50 year old plantations of Pinus sylvestris * with only Deschampsia flexuosa or without any undergrowth. The heathland is characterized by species-poor remnants of a dry heathland community, Genisto pilosae-Callunetum " and of stabilized sand, Spergulo-Corynephoretum. Locally patches of Molinia caerulea and spontaneous growth of Pinus sylvestris, Quercus robur, Juniperus communis and Frangula alnus occur.

The former arable fields are plots of between $0.5-5.5$ ha. They were abandoned in 1972 and originated from heathlands reclaimed for cultivation around 1900. The vegetation succession on these plots is from Chenopodietea and Aperetalia associations to vegetation with species from Artemisietea vulgaris and plantoginetalic majoris associations and finally to Koelerio-Corynephoretea and Nardo-Callunetea associations. The last two syntaxa were almost absent in 1975, when the rabbits were sampled (Van de Laar \& Slim, 1979). In 1975 the burrows were still mostly situated in the heathland.

Outside the study area there are meadows, Poo-Lolietum, heavily fertilized with manure.

- Nomenclature of taxa and syntaxa according to Heukels \& Van Ooststroom (1977) and Westhoff \& Den Held (1975) respectively. 


\section{METHODS}

Stomach contents and last faecal (hard) pellets in the colon minus ("rectum") of 25 rabbits ferreted and shot in Cranendonck between 10.00 and $14.30 \mathrm{~h}$ on 14 January 1975 were collected for analysis (Fig. 1). The analysis was conducted as described in Brüll (1973) with modifications by Immink (1977). Stomach and faeces contents were homogenized and from every sample $(n=50) 200$ particles were determined to species. Particles $<1 \mathrm{~mm}^{3}$ were discarded. The presence of a plant species in the sample is expressed as the percentage of the particles that belonged to that species.

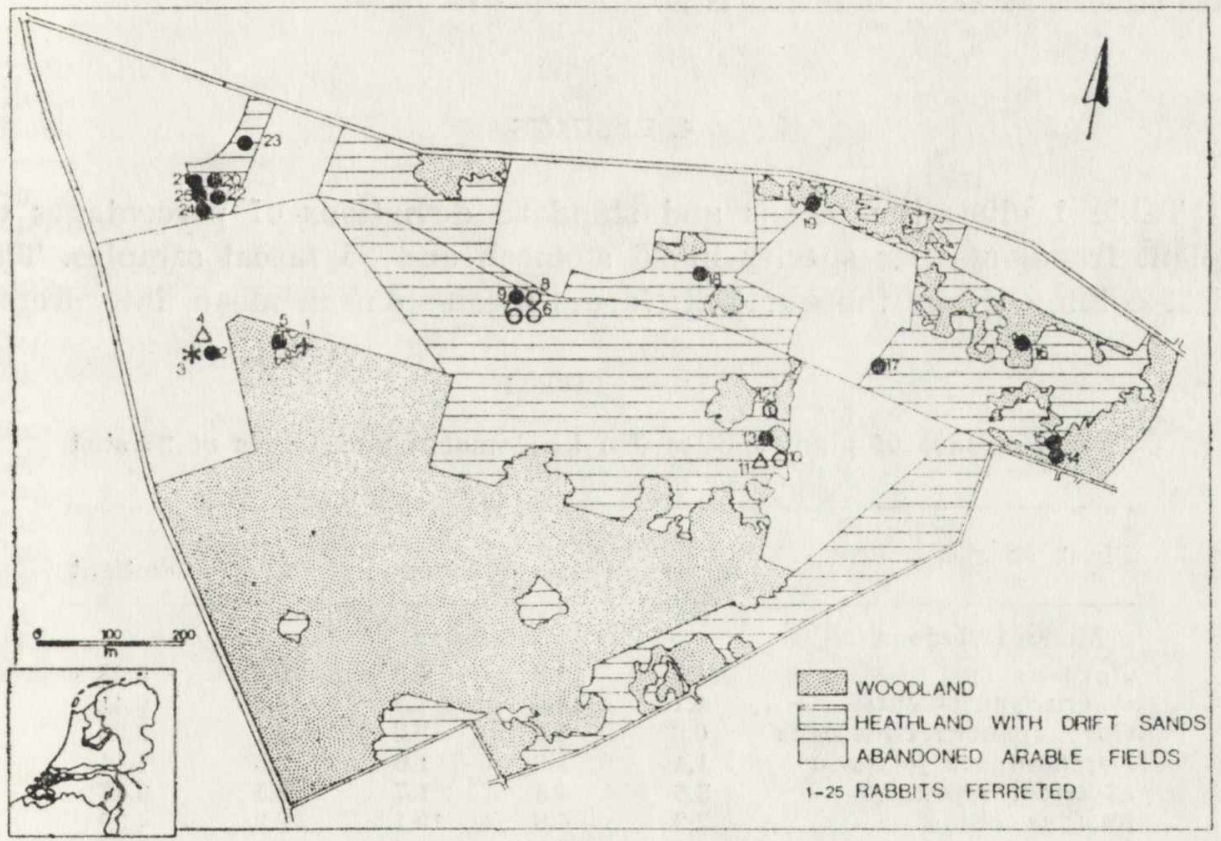

Fig. 1. Survey of the study area and situation of the warrens from which the rabbits were ferreted $(O=$ cluster I, $\Delta=$ cluster II, $\bar{c}=$ cluster III, $=$ cluster IV and $+=$ cluster $\mathrm{V}$ ).

Rabbits eat about $300 \mathrm{~g}$ roughage in 24 hours (Aitken \& Wilson, 1962) and the mean stomach fill of a wild rabbit is $45 \mathrm{~g}$ (Wallage, unpubl.). This means that the stomach contents collected represent one out of several meals of the previous night.

With faeces the case is less simple, as mixing of the contents of several meals happens in the digestive tract, especially in the caecum (Björnhag, 1972).

With the use of stained straw particles Björnhag (1972) showed that the first particles reach the distal part of the colon minus in 4 hours after the meal. The mean retention time in the rabbit for Phleum pratense was 5.3 hours (Uden et al., 1982).

Rabbits do practise coprophagy. Smaller particles $(100 \mu)$ are collected in the colon, packed into caecotrophes (soft pellets) and after defecation taken from the 
anus and consumed. Coprophagy need not concern us here as these very small particles are probably unidentifiable and lost in the analysis procedure as applied in the present study.

The set of 50 stomach and faecal contents is subdivided into groups by a cluster analysis based on group averaging. The program used is a part of BIOPAT, a program system for bioinformatic pattern analysis, developed by P. Hogeweg and B. Hesper, Department of Bioinformatics, University of Utrecht, The Netherlands. The stomach and faecal contents are considered as points in a multi-dimensial space, spanned by the composing plant species. Discontinuities in this cloud of points are depicted in dendrograms in which the vertical axis is a measure of mean square distance between subgroups. A set is split up at a high level when the distance between the subsets is large.

\section{RESULTS}

Table 1 gives the means and standard deviations of percentages of plant fragments per species in 25 stomach and 25 faecal samples. The last column shows the quotient: faeces mean/stomach mean, interpreted

Table 1

Presence of plant species $(\%)$ in stomachs and faeces of 25 shot rabbits.

\begin{tabular}{|c|c|c|c|c|c|}
\hline \multirow{2}{*}{ Plant species } & \multicolumn{2}{|c|}{ Stomach } & \multicolumn{2}{|c|}{ Faeces } & \multirow[b]{2}{*}{ Quotient } \\
\hline & mean & $\mathbf{s}$ & mean & s & \\
\hline \multicolumn{6}{|l|}{ Monocotyledons } \\
\hline Agrostis sp. & 1.3 & 1.8 & 0.3 & 0.8 & 0.23 \\
\hline Apera spica-venti & 4.1 & 11.6 & 1.7 & 6.1 & 0.41 \\
\hline Corynephorus canescens & 0.8 & 1.3 & 2.9 & 4.1 & 3.63 \\
\hline Deschampsia flexuosa & 1.4 & 1.6 & 1.6 & 2.8 & 1.14 \\
\hline Elytrigia repens & 3.6 & 4.5 & 1.7 & 2.5 & 0.47 \\
\hline Festuca ovina & 2.3 & 4.8 & 10.1 & 12.2 & 4.39 \\
\hline Holcus lanatus & 2.8 & 5.4 & 2.5 & 7.0 & 0.89 \\
\hline Lolium perenne & 20.1 & 15.7 & 16.7 & 16.0 & 0.83 \\
\hline Nardus stricta & 3.8 & 7.3 & 2.2 & 3.2 & 0.58 \\
\hline Phleum pratense & 12.6 & 8.9 & 18.1 & 11.8 & 1.44 \\
\hline Poa pratensis & 2.8 & 3.7 & 0.2 & 0.8 & 0.07 \\
\hline Poa trivialis & 1.7 & 2.0 & 0.0 & & 0.0 \\
\hline \multicolumn{6}{|l|}{ Dicotyledons } \\
\hline Achillea millefolium & 0.8 & 1.5 & 0.0 & & 0.0 \\
\hline Calluna vulgaris & 7.2 & 8.8 & 18.6 & 7.4 & 2.58 \\
\hline Cerastium sp. & 2.8 & 3.2 & 0.6 & 1.0 & 0.21 \\
\hline Erodium cicutarium & 0.4 & 0.9 & 0.0 & & 0.0 \\
\hline Plantago major & 0.6 & 1.1 & 0.1 & 0.6 & 0.17 \\
\hline Ranunculus repens & 0.4 & 0.7 & 0.6 & 1.8 & 1.50 \\
\hline Rumex acetosella & 1.6 & 2.3 & 0.0 & & 0.0 \\
\hline Rumex obtusifolius & 1.6 & 1.7 & 0.0 & & 0.0 \\
\hline Stellaria media & 3.2 & 4.4 & 03 & 0.7 & 0.09 \\
\hline Taraxacum sp. & 15.0 & 7.5 & 0.1 & 0.4 & 0.01 \\
\hline Trifolium repens & 0.9 & 1.8 & 00 & & 0.0 \\
\hline Urtica dioica & 4.5 & 3.4 & 3.2 & 3.3 & 0.71 \\
\hline
\end{tabular}


as a measure of digestibility. The diet of the group of 25 rabbits contained 24 foodplants identifiable in at least 6 of the samples. Poa trivialis and 5 species of dicotyledons found in the stomaches were not found in the faeces at all. Plantago and Taraxacum were in the faeces only found once. Generally, dicots have a higher digestibility than monocots. Exceptions here are Poa with a relatively high and Calluna and Ranunculus with a low digestibility.

Table 2

Means of percentage of plant fragments in stomach contents in 5 clusters.

\begin{tabular}{|c|c|c|c|c|c|}
\hline $\begin{array}{l}\text { Cluster number } \\
\text { Rabbit number }\end{array}$ & $6-8, \stackrel{I}{10,12}$ & $\underset{4,11}{\text { II }}$ & $\begin{array}{l}\text { III } \\
3\end{array}$ & $\begin{array}{l}\mathrm{V} \\
1\end{array}$ & $2,5,9,13-25$ \\
\hline $\begin{array}{l}\text { Agrostis sp. } \\
\text { Apera spica-venti } \\
\text { Calluna vulgaris } \\
\text { Cerastium sp. } \\
\text { Corynephorus canescens } \\
\text { Deschampsia flexuosa } \\
\text { Elytrigia repens } \\
\text { Festuca ovina } \\
\text { Holcus lanatus } \\
\text { Lolium perenne } \\
\text { Nardus stricta } \\
\text { Phleum pratense } \\
\text { Poa pratensis } \\
\text { Ranunculus repens } \\
\text { Stellaria media } \\
\text { Urtica dioica } \\
\text { Vegetation type }\end{array}$ & $\begin{array}{c}3 \\
1 \\
20 \\
3 \\
3 \\
2 \\
0 \\
1 \\
3 \\
2 \\
18 \\
2 \\
1 \\
1 \\
8 \\
5 \\
\text { Heathland }\end{array}$ & $\begin{array}{c}1 \\
42 \\
3 \\
4 \\
2 \\
3 \\
0 \\
3 \\
2 \\
0 \\
0 \\
2 \\
0 \\
0 \\
13 \\
4 \\
\text { Abandoned } \\
\text { arable } \\
\text { fields }\end{array}$ & $\begin{array}{r}2 \\
3 \\
0 \\
4 \\
0 \\
2 \\
10 \\
2 \\
1 \\
0 \\
0 \\
14 \\
3 \\
2 \\
0 \\
1\end{array}$ & $\begin{array}{r}0 \\
0 \\
0 \\
12 \\
0 \\
2 \\
0 \\
24 \\
0 \\
23 \\
0 \\
5 \\
0 \\
0 \\
0 \\
9 \\
\text { ed }\end{array}$ & $\begin{array}{c}1 \\
1 \\
5 \\
2 \\
0 \\
1 \\
5 \\
1 \\
3 \\
30 \\
1 \\
18 \\
4 \\
0 \\
1 \\
4 \\
\text { Meadow } \\
\text { outside } \\
\text { reserve }\end{array}$ \\
\hline
\end{tabular}

Figure 2 is a dendrogram of the stomach contents. Only the 16 plant species found more than once in the faeces were used. The 25 stomach contents can be subdivided into 5 clusters.

Table 2 gives per cluster the means of percentages of plant fragments per species. These clusters represent different vegetation types in which the rabbits recently took their meals. So rabbits of cluster I recently foraged in heathland with Calluna and Nardus, whereas rabbits of cluster IV recently took their meals in a vegetation with Lolium and Phleum.

We can assume to eliminate differences between stomach and faeces contents due to differential digestion by dividing the percentages of plant fragments per species in the faeces by the digestibility quotient. 
Cluster analysis of the 25 stomach contents and the 25 modified faeces contents together results in the dendrogram shown in Figure 3.

The 5 clusters of Figure 2 can be recognized in Figure 3 and all the faeces contents, except no. 43 (rabbit no. 18) can be classified in those clusters. In 15 cases the faeces content of a certain rabbit can be found

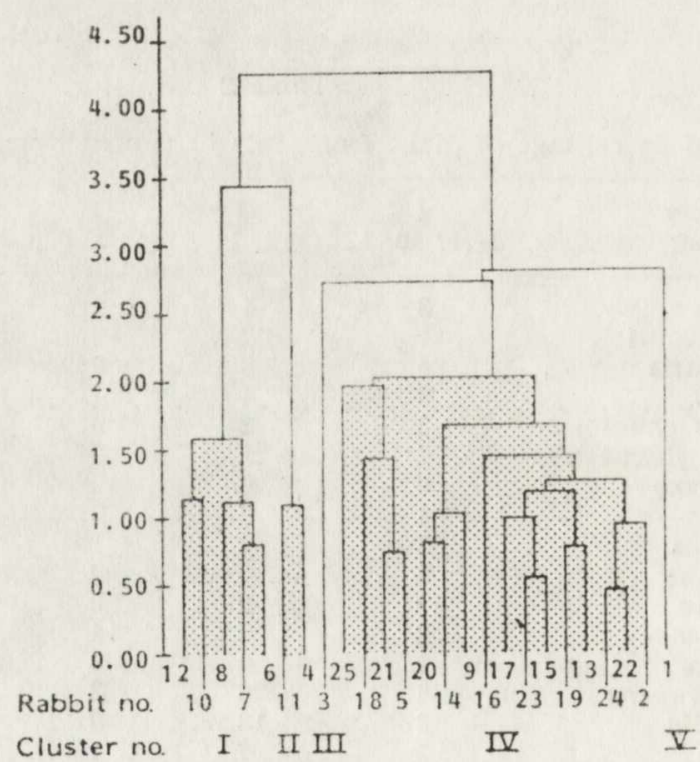

Fig. 2. Dendrogram of stomach contents. Horizontal axis: rabbit number (1-25); vertical axis: mean square distance between subgroups.

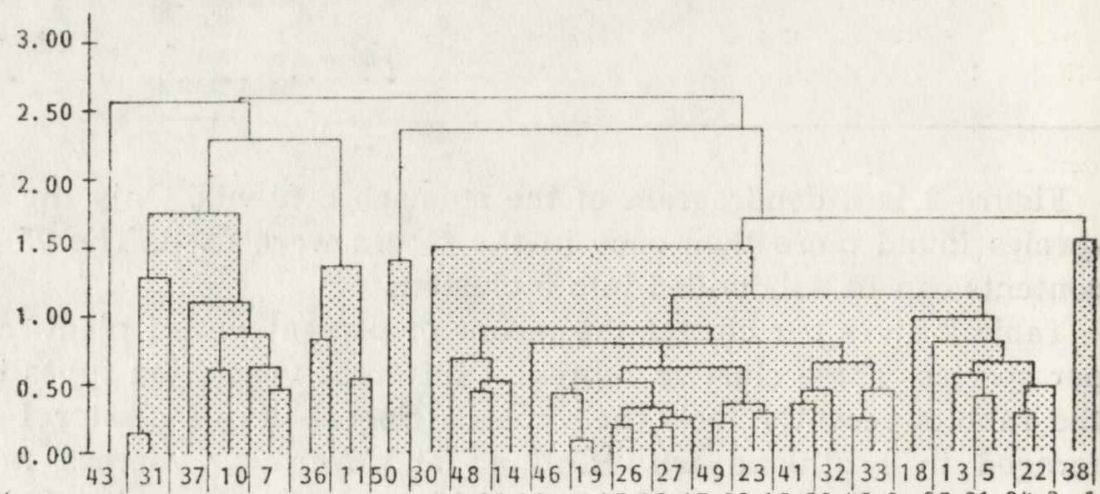
'Rabbit'no. $\quad 342912 \quad 8 \quad 6 \quad 35 \quad 4 \quad 3 \quad 16204044474217281539459925212421$ Cluster no. VI I II III IV I

Fig. 3. Dendrogram of stomach contents and faeces contents together. Horizontal axis: rabbit number (faeces of rabbit $i=i+25$ ); vertical axis: mean square distance between subgroups. 
in the same cluster as the stomach content of the rabbit. However, 10 rabbits have their faeces content in another cluster than their stomach content. Evidently they did forage successively in different vegetation types. Table 3 gives an enumeration of these changes.

Table 3

\begin{tabular}{|c|c|c|}
\hline Rabbit & Stomach & Faeces \\
\hline 1 & V & IV \\
\hline 3 & III & IV \\
\hline 4 & II & I \\
\hline 7 & I & IV \\
\hline 8 & I & IV \\
\hline 9 & IV & I \\
\hline 10 & I & II \\
\hline 13 & IV & $\mathrm{V}$ \\
\hline 18 & IV & VI \\
\hline 25 & IV & III \\
\hline
\end{tabular}

\section{DISCUSSION}

Several authors have paid attention to the differential digestibility of plant species as complicating the assessment of the diet of a herbivore from the composition of its faeces, even in nonruminants. Batzli \& Pitelka (1971) and Neal et al. (1973), working respectively with Microtus californicus and $M$. pennsylvanicus, and Owaga (1977) working with equus burchellii found a high correlation between stomach and faecal contents and used discrepancies between stomach contents and faeces to establish correction factors for different plant species. They all noted that dicotyledons more than monocotyledons become unidentifiable or were digested. Wydeven \& Dahlgren (1982) pointed to the importance of "short-term changes in the diet" in causing these differences, but failed to separate the effects from those of differential digestion.

In a patchy environment with different vegetation types, ine information regarding the habitats in which the animal has been foraging can be used to assess habitat use and daily dispersion.

In this study it could be shown that the rabbits foraged either on abandoned arable land (cluster II), heathland (cluster I) or on fertilized meadow outside the reserve (the largest cluster: IV). Some rabbits must have travelled more than $200 \mathrm{~m}$ to reach the foraging places (see Fig. 1). 
No evidence for foraging in the woodlands was found, even for the rabbits living in it.

The present study reveals clearly the change of foraging areas by studying individual rabbits. Rabbits 7 and 8 for example, have probably taken their last meal, early in the morning, in the heathland around their burrows, while they foraged earlier on the fertilized meadow outside the study area. Observations like the ones presented in this study can therefore contribute to the understanding of habitat use (especially foràing) by rabbits in a diverse, patchy environment.

Acknowledgements: Many thanks are due to Piet Oosterveld who supervised the project in Cranendonck and to the State Forestry Service for their willingness to let us work there and for their assistance in dissecting the rabbits shot. Gerbera Weijdema competently analysed the faeces. Rasik Bhadresa (Colchester, UK) was so kind as to correct the English. We thank Prof. dr. K. Bakker and Eddy van der Meijden (University of Leyden) for their interest during the study.

\section{REFERENCES}

1. Aitken F. C. \& Wilson W. K., 1962: Rabbit feeding for meat and fur. Rowett Institute, Aberdeen. Techn Comm. no. 12: 1-63.

2. Batzli G. O. \& Pitelka F. A., 1971: Condition and diet of cycling populations of the Californian vole. J. Mamm., 52: 141-163.

3. Bhadresa R., 1982: Plant-rabbit interactions on a lowland heath. Thesis, King's College, University of London: 1-263.

4. Björnhag G., 1972: Separation and delay of contents in the rabbit colon. Swedish J. Agr. Res., 2: 125-136.

5. Brüll U., 1973: Wildfutterpflanzengesellschaften und Futterwert der von Feldhasen (Lepus europaeus Pallas) genutzten Pflanzen. Dissertation, Universitat Hamburg: 1-162.

6. Chapuis J. L. \& Lefeuvre J. C., 1980: Evolution saisonnière du régime alimentaire du lapin de garenne, Oryctolagus cuniculus (L.), en Lande: Résultat de deux ans d'analyses. Bull. Ecol., 3: 587-597.

7. Heukels H. \& Ooststroom S. J. van, 1977: Flora van Nederland. 19th ed. Wolters-Noordhoff: 1-925. Groningen.

8. Immink H. J., 1977: Voedselkeuze en graasdrukbepaling van het wilde konijn Oryctolagus cuniculus L. (1758) in het CRM-reservaat "Baronie Cranendonck". Internal report, Rijksinstituut voor Natuurbeheer, Leersum.

9. Laar J. A. J. van de \& Slim P. A., 1979: Veranderingen in flora en vegetatie van de verlaten landbouwgronden in het CRM-reservaat Baronie Cranendonck na vijf jaar begrazing door IJslandse pony's (1972-1977). Internal report; Rijksinstituut voor Natuurbeheer, Leersum.

10. Neal B. R., Pulkinen D. A. \& Owen B. D., 1973: A comparison of faecal and stomach contents analysis in the meadow vole (Microtus pennsylvanicus). Can. J. Zool., 51: 715-721.

11. Oosterveld P., 1983: Eight years of monitoring of rabbits and vegetation development on abandoned arable fields grazed by ponies. Acta Zool. Fenn., 174: 71-74.

12. Owaga M. L. A., 1977: Comparison of analysis of stomach contents and faecal samples from zebra. E. Afr. Wildi. J., 15: 217-222. 
13. Uden P., Hounsaville T. R., Wiggans G. R. \& Van Soest P. J., 1982: The measurement of liquid and solid digesta retention in ruminants, equines and rabbits given timothy (Phleum pratense) hay. Br. J. Nutr., 48: 329-339.

14. Westhoff V. \& Held A. J. den, 1975: Plantengemeenschappen in Nederland. Thieme: 1-324. Zutphen.

15. Wydeven P. R. \& Dahlgren R. B., 1982: A comparison of prairie dog stomach contents and faeces using a microhistological technique. J. Wildl. Manage., 46: $1104-1108$.

Accepted, September 20, 1985.

J. Marijke WALLAGE-DREES, Herman J. IMMINK, Gerrit-Jan DE BRUYN

i Pieter A. SLIM

\section{ZASTOSOWANIE MIKROSKOPOWEJ ANALIZY FRAGMENTOW ROSLINNYCH DO BADANIA KROTKOTERMINOWYCH ZMIAN DIETY KROLIKOW.}

\section{Streszczenie}

Analiza mikroskopowa fragmentów epidermy w żołądku lub $w$ kale jest częsta metodą badania diety roślinożerców. Dwa czynniki mogą powodować różnice między próbami pobranymi z żołądka i z kału tego samego osobnika: (1) inna strawność i czas retencji różnych gatunków i części roślin, (2) różnice pomiędzy posiłkami (krótkoterminowe zmiany diety). W pracy stosunek średniej ilości danej rośliny $w$ kale do ilości $w$ żołądku interpretowany jest jako miara strawności i używany jako przelicznik dla zróżnicowanej strawności roślin tego gatunku. W badaniach pokarmu królików (Oryctolagus cuniculus L.) wykryto, że niektóre osobniki zmieniały teren żerowania w ciągu nocy. Obserwacje takich krótkoterminowych zmian dostarczaja informacji o behawiorze żerowania $w$ heterogennym srodowisku. 